\title{
MASSIVE OPEN ONLINE COURSES AS AN ALTERNATIVE FORM OF HIGHER EDUCATION
}

\author{
Svitlana Dobrovolska, Mariana Opyr, Natalia Myronenko, Svitlana Panchyshyn
}

\author{
Lviv National Agrarian University
}

\section{Resume:}

A university is an institution of higher learning. It is a place to discover who really you are. Is coming to university really necessary if you want to be educated? Employment opportunities are increasing for business school grads and the number of grads is increasing even faster. If someone is looking for career in business there is a need to consider the location analytics. Insights will help you to make better business decisions. Getting educated is no longer just sitting in the classroom and listening to teacher lecture. Time has changed the structure, methods and purpose of teaching. Massive Open Online Courses (MOOCs) are changing the face of education. Companies supporting MOOCs are Coursera, Udacity, EDX offering an alternative to traditional education, supporting online courses, with access anywhere, anytime, and for anyone. MOOCs offer transparency of teaching methods among an academic community, resulting in better teaching. The potential of digital technology is endless. Bringing university courses online allows the best professors to share their brightest ideas with the world, welcoming students and independent learners of all ages. In fact, it's already happening. When a few Stanford University professors opened their courses to the world, it was a monumental success, with more than a quarter of million students enrolling in just two courses. Since then, professors of the world, finest academic institutions created hundreds of open courses. Open courses are not about simply filming a lecture; it is about creating custom content designed specifically for online teaching. An open course transforms traditional course concept using multimedia formats and allows an easy interaction online. Millions are already learning online.

\section{Key words:}

massive open online courses; learning online; traditional education; platform; massive online course provider; grading; certification.
Анотація:

Добровольська Світлана, Опир Маріанна, Мироненко Наталія, Панчишин Світлана. Масові відкриті онлайн-курси як альтернативна форма вищої освіти.

Університет - це вищий навчальний заклад. Він дає змогу з'ясувати, ким ви насправді є. Чи дійсно потрібен вступ до університету, якщо ви хочете здобути освіту? Можливості працевлаштування збільшуються для ділових шкіл, кількість випускників яких збільшується дуже швидко. Якщо ви мрієте про кар'єру в бізнесі, необхідно врахувати просторову аналітику. Статистика допоможе вам ухвалити найкращі бізнесрішення. Здобуття освіти більше не обмежується відвідуванням навчальних закладів і безпосереднім слуханням лекцій викладача. Час змінив структуру, методи та мету навчання. Масові відкриті онлайн-курси (МООС) роблять іншим «обличчя» освіти. Компаніями, що підтримують МОOC, $є$ Coursera, Udacity, EDX, які пропонують альтернативу традиційній освіті, підтримуючи онлайн-курси з доступом у будь-якому місці, у будь-який час та для будь-кого. МООС пропагують прозорість методів навчання серед академічної спільноти, що сприяе якнайкращому викладанню. Потенціал цифрових технологій нескінченний. Викладання університетських курсів в Інтернеті дає змогу найкращим викладачам ділитися своїми найяскравішими ідеями зі світом, заохочуючи до навчання студентів та незалежних слухачів різного віку. Сьогодні це вже відбувається. Коли кілька професорів Стенфордського університету відкрили свої курси світу, це був монументальний успіх, оскільки всього лише на два курси записалося понад чверть мільйона студентів. Відтоді професори найкращих світових академічних установ створили сотні відкритих курсів. Відкриті курси - це не просто зйомка лекції, а створення індивідуального контенту, розробленого спеціально для онлайн-викладання. Відкритий курс перетворює традиційну концепцію курсу за допомогою мультимедійних форматів і забезпечує просту взаємодію в Інтернеті, де навчаються вже мільйони.

Ключові слова:

масові відкриті онлайн-курси; навчання онлайн; традиційна освіта; платформа; масовий провайдер онлайн-курсів; оцінювання; сертифікація.
Аннотация:

Добровольськая Светлана, Опыр Марианна, Мироненко Наталья, Панчишин Светлана. Массовые открытые онлайн курсы как альтернативная форма высшего образования.

Университет - это высшее учебное заведение, которое дает возможность выяснить, кем вы являетесь на самом деле. Действительно ли необходимо поступление в университет, если вы хотите получить образование? Возможности трудоустройства увеличиваются для деловых школ, количество выпускников которых растет очень быстро. Если вы мечтаете о карьере в бизнесе, необходимо учитывать пространственную аналитику. Статистика поможет вам принять лучшие бизнесрешения. Получение образования больше не ограничивается посещением учебных заведений и непосредственным слушанием лекций преподавателя. Время изменило структуру, методы и цели обучения. Массовые открытые онлайн курсы (МOOC) делают другим «лицо» образования. Компаниями, поддерживающими МOOC являются Coursera, Udacity, EDX, которые предлагают альтернативу традиционному образованию, поддерживая онлайн курсы с доступом в любом месте, в любое время и для каждого. МООС пропагандируют прозрачность методов обучения среди академического сообщества, что способствует наилучшему преподаванию. Потенциал цифровых технологий бесконечен. Преподавание университетских курсов в Интернете дает возможность лучшим преподавателям делиться своими яркими идеями с миром, привлекая к обучению студентов и независимых слушателей разного возраста. Сегодня это уже происходит. Когда несколько профессоров Стэнфордского университета открыли свои курсы миру, - это был монументальный успех, поскольку всего лишь на два курса записалось более четверти миллиона студентов. С тех пор профессора лучших мировых академических учреждений создали сотни открытых курсов. Открытые курсы- это не просто съемка лекции, а создание индивидуального контента, разработанного специально для онлайн преподавания. Открытый курс преобразовывает традиционную концепцию курса с помощью мультимедийных фрорматов и обеспечивает простое взаимодействие в Интернете, где учатся уже миллионы.

\section{Ключевые слова}

массовые открытые онлайн-курсы; обучение онлайн; традиционное образование; платформа; массовый провайдер онлайнкурсов; оценивание; сертификация.
Problem setting. Massive Open Online Courses have developed into an alternative form of Higher
Education, with the result that, at the current time, various universities are adopting such educational 
strategy. This is due to their eagerness to accommodate the educational demands of the masses and to achieve internationalization and visibility before the world, or simply as an effective business model. This comes in spite of the fact that the quality of content, methodology, evaluation, learning results, lack of feedback and credibility of such courses, among other things, has been called into question. This research paper is the result of an analysis of diverse bibliographic sources concerning the development of MOOCs, and the participative experiences on various courses of the major MOOC platforms, with the aim of demonstrating the principal problems and challenges of MOOCs and how these could be overcome from a teaching, technological and organizational perspective; in such a way that in the future, this teaching modality could contribute to and strengthen this form of inclusive education.

Task setting. The aim of this article is to analyze different bibliographical resources concerning the development of MOOCs and experiences in observing several of those courses; with the purpose of exposing our points of view, regarding the way some problems can be overcome from a pedagogical, technological and organizational perspective.

Analysis of recent researches and publications. In the exhaustive analysis of the path which MOOCs have taken, it was observed that this phenomenon, from the outset, has generated controversy. On the one hand are the defenders of MOOCs who claim that this type of learning dramatically transformed Higher Education and those MOOCs and make a significant contribution the field of education [2]. It is also claimed that MOOCs are a revolution which has great potential within the world of education [8]. Nevertheless MOOCs have not achieved the objectives for which they were created, nor had the desired impact. The other side argues that MOOCs should be seen as a futile experience [3]. An expert in e-learning, Albert Sangrá pointed out that MOOCs work very well as a marketing tool for universities to gain visibility in a world market, without any disruption to learning. But what are MOOCs and how are they characterized? Many researchers state that MOOCs are part of the evolution of e-learning, a category of online course, open and participative distance learning courses which all people can access and participate in via a computer with an internet connection [4]. To date their definition is not clearly standardized further than the characteristics associated with the term MOOC (Massive open Online Course): Massive, implying that there are no limits on the number of participants, open in the sense that any person can register for free, open content i.e. fermium model [7]. Their online character implies that these courses are distributed via the internet and course means that they must have a coherent structure, learning objectives and program content which allows for goals to be reached and learning achieved. However, many MOOCs do not currently fulfill these characteristics as the following epigraphs illustrates.

Scope of research. Education has not really changed in the past 500 years. Only the last big innovation in education was the printing press and the textbooks. Everything is changing around us - from healthcare to transportation, everything is different, but education hasn't changed. It's possible to transform education, both in quality, in scale, in excess through technology. For example, education can be transformed through online technologies at massive online course provider. It is about reengineering it, micromanaging it. It is necessary to re-imagine it. One needs to go from lectures from blackboards to online exercises, online videos, go to interactive virtual laboratories, gamification, and go to completely online grading, peer interaction and discussion boards. Some organizations are already applying these technologies to education through Massive Open Online Courses (MOOCs) to increase the excess to education.

There are some key ideas that make the online learning good. One idea is active learning. The idea here is rather then have students work in class watch lectures. It is what it is called lesson. Lessons are interleaving sequences of videos and interactive exercises. So, students might watch a 5-7 minutes video and follow that with interactive exercises. Teaching by asking questions that is a form of learning, called active learning, and promoted in 1972 by really known paper of Craik and Lockhart. They said and discovered that learning and retention really relate strongly to the depth of mental processing. Students learn much better when they are interacting with the material.

The second idea is self-pathing. This idea offers videos, interactive engagements. This form of selfpathing can be very helpful to learning.

The third idea is instant feedback. The point of this idea is that computer grades the exercises. With instant feedbacks students can try apply answers, and then get it wrong, they can give instant feedback, and then they can try it again. And this is really becoming very engaging to get the instant feedbacks. An instant feedback turns teaching moments into learning outcomes.

The next great idea is gamification. It is when all learners are engaged with interactive videos. It is possible to apply this technique to learning and build these online laboratories.

Fifth idea - is peer learning. So, here discussion forums are used as interaction to help students learn.

So, these technologies can really help in revolution of education. It will also solve a practical problem of MOOCs. These courses can be used as a 
next generation textbooks. It becomes a tool at the teachers' arsenal.

Finally, try to re-imagine education. Move from books to tablets, from big and modern school buildings to digital dormitories, but at the end of the day it will a need for one lecture hall in a university.

What are MOOCs? MOOCs - Massive Open Online Courses. MOOCs are courses provided by universities all over the world. MOOCs have had so much success that hundreds of universities around the world have followed the experience. Reaching today to around 700 universities and they offer more than 850 courses. Due to that popularity MOOCs have been qualified as the revolution of online learning. Therefore, many researches and scientists study to take a look at these MOOCs to try to understand how they work. To answer this question it is necessary to base on theory of motivation. Why? Because motivation is acknowledge being one of the biggest predictors of performances in learning. There are many theories of motivation but one of the most popular is self-determination theory. According to this theory there are three basic and universal needs. Taking a look at MOOCs it is why they are so popular. Because actually they help with the characteristics and tools to fill in these needs. Take a look together at the needs and how MOOCs help to fulfill them.

The first one is the need of autonomy. So, the need of autonomy meets that the necessity of a behavior to consume preferences and desires in order to have a better performance. And MOOCs are great in that way because they offer to choice for the place where to learn or when to learn, and more specifically, what to learn. As learners can choose whatever course they want, but even better, they don't even have to follow the whole course. They can choose the chapter of the course needed and just study that. Students can even get a certificate which is called "Badge" that certifies success on that particulate chapter. But how students are still experiencing the faculties is because they don't really know how to use these tools. So, in terms of autonomy what happens is that many students get lost with all these possibilities. And they forget to make a choice. They have to choose preferences. There are thousands of flavors of knowledge. The more curious students are, the more they will be temped to involve to all of these courses. When students involve in MOOCs first thing - check agenda. Look at how much time they have. Maybe start with one MOOC. The one, they prefer the most. And if the students have more time they can involve to another one. Also in terms of autonomy students can study wherever they want, pick a place for them feel the most concentrated and also comfortable. But it may not be too comfortable.

The second need is the competence which means that when learners want to pursue something it is necessary to feel competence at the task. MOOCs help again there as well, as they offer courses that are at different levels of the faculties. So, how to use that well? Check the visit of that course before being involved. Also courses are provided by many languages so, choose the course that is in the most comfortable language. MOOCs provide students also many times with subtitles that can help to follow the course, if it is not mother tongue. But studies have shown that the more the courses are technical, the more it is complicated to follow the course. Imagine, for an instance, an English speaking student and he/she wants to follow a class on quantum physics. $\mathrm{He} / \mathrm{she}$ has to watch out for incompetence before being involved to the course. Also try to fill in the assignments and the quizzes that are provided even if he/she does not want to get a certificate. It just helps to keep track with knowledge and it gives a feeling of engagement to the course. Last, but not least - is the feeling of relatedness, which means to feel motivated to engage in an activity needed to feel related to others, to belong to a group. And not only this factor is one of the most important in motivation, it is also what makes MOOCs more special. Online courses provide students with so many tools to connect with other learners and teaching staff. They have to like forums, Google hangouts, and more other tools that will help to be in connect with them. So, students have to stay connected. They can also create their own community of learners. As the conclusion of this ideathe quote of Benjamin Franklin may be used: "We are all born ignorant but one must work hard to remain stupid".

While talking about MOOCs there are a lot of positives and negatives of them. Here are some positives:

- Great alternative to traditional learning

- recorded content, video, presentations

- online exams, eLearning material

- do work on own time. Anywhere, anytime, less or no travel

- great for going back to school

- give more self-responsibility

- repeat

- $\quad$ go to specific places and hear again

- cost effective

- consistent course

One of the biggest advantages of online learning is excess anywhere, anytime. So, students can excess it while traveling, they can excess it from home, from office. There is no need to be physically present in a single place. This gives a freedom from geographical location. Next, if the learners want to get it repeated, they can play it again and again.

One more advantage is cost effective. In September 2011 two Stanford university professors offered a computing science course online for free And much to everybody's surprise 160,000 people 
around the world signed up to take the course, and a little bit humbling was that 20,000 of those students completed the course and passed. For example, University professor has been teaching for 33 years. Most Years he/she has taught multiple courses, multiple sections, large classes, small classes. In his/her entire 33 years combined he/she hasn't come close to teaching 20,000 students if MOOCs did that in one term. What's happened since then? Everyone talked about the year of the MOOC that this was going to revolutionaries University education. But what's been happening the move to online has been going very slow. There's lots of resistance in the system to change but the realities that universities are under enormous cost pressures whether people like MOOCs or hate them. The courses do offer a way to educate more students at less cost. The important thing here is that history tells that once technology gets its tentacles and sinks it into something. It is disruptive and change is inevitable. It will happen. The standard classroom teaching models that are used are hundreds of years old. Look around. Maybe it's time for a change. Think about MOOCs and what it offers for students. Imagine being able to take a university course anytime, anywhere and at own pace that it is not bound to showing up Monday, Wednesday, Friday at a physical location at the university to take course.

From university's point of view these online course are taking by 10,000 students, the cost of adding one more student so there's ten thousand and one is zero. These courses can be made available free or at low costs of the world and basically reach everybody, especially those people who cannot afford University education. Many people call this the democratization of knowledge.

But there are also some negatives.

fun is missing

no a face to face environment

no human interaction with teachers

doesn't work on social skills

- some teachers have no skills to run an online courses

- character imbibing - human behavior. Students learn large from the teachers.

It's not just a language alone, it's body language, kindness, the way one is attracting the people, giving or taking respect - those character imbibing are missing while online learning.

In total the active learning is very good when it comes to gain knowledge; it is not very good when it comes to soft factors/character building. There is a need to build a character; online learning is not that good. When one wants to build a character, he/she needs to be physically presented.

And the predominant platform offers MOOC that they have forms that rely on results of learning science from year's back, from the 1980s, when Carl
Wieman did the pioneering work on interrupting lectures. He concluded that 50 minutes lecture is perhaps the least efficient mode of transmitting information from one human being to another and founded this by interrupting lecture classes with questions, or quizzes, or clickers, or something to distract the students from the tasks they are following to. That would actually improve the attention and here he found results that the retention of the content of the lecture would double if students did this interruption every 6 or 10 minutes. MOOCs are based on a short modular video, frequently interrupted with in video quizzes to keep you going. Assessments of tests are typically machine graded and since if teachers got 2000 people in a classroom it's not too easy to grade the exams and quizzes and papers, the peer grading for non-machine gradable contents can be used.

What is actual effectiveness and impact of MOOCs? Is online learning effective? There are a lot of studies now of content mastery with MOOC relative to regular classes. And they show that MOOC is better than lecture course. The best is the MOOC with facilitation. Learners often study on their own, do exams and tests, but they have no opportunity to talk about material with a live person.

The number one factor was that they had recently taken a course on the reason to get a certificate. Two years ago Linkedln published a survey counting up who a service tabulation of the most frequently cited credentials on Linkedln and Coursera was number two after that went ahead of all the traditional industry certifiers you know any of the standard industry certifications of CompTIA specialist or a cisco network technician or whatever. The only certificate more frequent than Coursera in 2015 was Microsoft but now Microsoft owns Linkedln.

Companies are increasingly recognizing the need to provide serious, substantive on the job education for their employees. Two major use cases are to upskill and re-skill particular categories of employees and to become an employer of choice for millennials by providing the tools for professional development. A market extension to enterprise has provided forty enterprise customers in the first year. Udacity, edX have also entered the enterprise market. They also recognize that they have needs to update the skills of their learners. So we are offering an Udacity within which is narrowly more focused on computer science and derivative type the jobs and now edX all have gotten into this area. We are finding it we are like responding to it to a need that's very much perceived. Corporate training and learning development on the job has been done by internal staff. And they are not the best people to bring people up to date in these rapidly changing areas and the quality except in a few places that have really strong reputations for training like Goldman Sachs and McKenzie. The quality of 
the training programs is just not great and people recognize that. Even the corporate trainers can see that their stuff is not good now. So hit a chord and the adoption is very rapid. It is read 40 businesses sign up within the first year. Most of them now are being the first renewal cycle and they are all trading up and wanting more. More employees exposed to these government workforce development programs. Online education can breathe new life into workforce development programs. Similar situation, there are unemployed and underemployed people all over the world and it is made more traction with internet foreign governments. Although, doing a program in the state of Maine and another interesting program for people in the last six months of military service to sort them up for the transition. Pakistan, for example, has a program where they identify the top one percent of their high school seniors. Give them a laptop. Now they get a laptop and they get access to course. Certifications help to move along the careers. For example, Kazakhstan is starting a financial centre in the capital Astana trying to become the Central Asian financial hub. So what they've done is that they've got a training program to teach people finance, basic financial skills and then how to get jobs as a financial analyst or an accountant.

The other, the opposite end of spectrum is recognizing that a lot of our university partners actually want to explore the idea of offering degrees online. Many of surveyors of these degrees are not exactly the quality institution that are recommended to anyone. But in the USA today, $15 \%$ of all students enrolled in degree programs, master's programs, are entirely online. High-quality masters programs such as Udacity and Coursera offer master's programs from top-tier universities for a very much reduced prices. Costs of top-tier online master's degrees are as low as $20 \%$ of residential equivalents. Learners were surveyed. Ninety percent of them said that the consideration of residential program was not in their decision set. It was a question on getting a degree online or not getting it at all. They were on average ten years older than people in the corresponding programs. They were in jobs, mostly they had families. Basically the thirty-something years old are able to get the same kind of advanced education that the twenty-something years old gets today on campus. Here is the future of higher education and it's not very far off. By 2030 the high quality universities will be offering high quality undergraduate and graduate programs on campus. Most of the top-tier universities by 2030 will have high quality online master's programs fully online. There will be hybrid programs too. Students do most of the program online and then come for one semester or two weeks or whatever to the campus. Undergraduate courses increasingly and probably in state universities being offered for credit, so it is possible to transfer among system schools. Some of these problems of higher education abroad and realizing aspirations of many developing countries are simply unreachable.

So, MOOC platforms and micro-credentials enable universities to serve learners throughout a lifetime. By 2030, top-tier University will provide:

- high quality undergraduate and graduate degree programs on campus;

- high quality master's degree programs fully online;

- undergraduate courses for credit online;

- courses for thousands of universities worldwide, enabling the global expansion of university education at reduced cost;

- Courses and degrees for enterprises and government workforce development programs.

All in all just reaching more and more people and having an impact on their lives that's a positive point. So the mission of the research university is to advance human knowledge through research and to disseminate knowledge through publication and teaching. What the MOOC allows and what technology more broadly allows is the dissemination mission to be increased by orders of magnitude.

There're some myths about MOOCs. First, people talk about the low completion rate. The universities gets $18 \%$ by putting a lot of time and effort into producing high-quality courses and it's reflected in more people taking and completing the courses than other universities. If it's free and students just drop it. But what studies have shown if universities just charge a nominal amount $40 \$$ what a bargain for a University course $\$ 40$ guess what completion rates zoom to $65 \%$. A little bit of money and people are incented to complete the course.

The second myth said that people who took MOOCs were disproportionately educated, male and wealthy. $32 \%$ of the people who take courses have no degree. $35 \%$ only have a Bachelor degree, $54 \%$ are female and $48 \%$ report low or no wages.

Another thing, people criticize MOOCs boring PowerPoint with voices. The top institutions put a lot of time and effort to involve interactive software applications, periodic quizzing on location shooting. Universities put a lot of high production values to produce an outstanding product.

Another myth is that MOOCs are going to eliminate classrooms. It's patently false. There is no one-size-fits-all type of teaching and learning online is perfect for some classroom one-on-one mentoring suits others.

This leads to three big ideas. First, the courses should be adopted for credit at universities. Most Universities offer courses to students accept it for credit. It enriches educational offerings, to be respectful to the student to offer, to give them access 
to the kinds of courses that they want to take. Second big idea, work together on developing a course. All the courses are largely the same. Talk about a massive waste, talk about an enormous amount of duplication. With a huge reduction in duplication and it is possible to make an enormous cost savings.

The third big idea is do not stop with the course. Put an online degree there, work together to produce a superb on-line degree that allows students to pursue at their own pace wherever they want a high quality university education

Conclusions. Technological advances have resulted in a journey towards a digital world, where MOOCs have emerged with the purpose of providing massive access to knowledge; feeding the growing demand for Higher Education, an objective which to date has not been fully achieved. Nevertheless, MOOCs, despite their problems, represent an alternative form of education. It is therefore necessary to re-think MOOCs from a pedagogical, technological and organizational view point. The digital literacy of tutors and students is a key for participation on MOOCs, with the aim that these participants acquire digital, social and organizational competence. Furthermore MOOCs need to be incorporated within the formal learning sphere, thus enriching this mode of education. Undoubtedly technological tools such as data sourcing, learning analysis and web semantics combined with artificial intelligence would help MOOCs, above all, to overcome the problems that they currently face with regard to interaction and feedback. It is necessary to further develop definitions of methodologies for the process of teaching and learning in virtual environments; taking into consideration the massive characteristic of MOOCs, an aspect which itself generates problems.

\section{References}

1. Craik F. I. M., Lockhart R. S. Models of Memory. Introducing Psychological Research. Palgrave, London, 1996.

2. Daniel J., Cano E. V. and Gisbert M. The future of MOOCs: Adaptive learning or business model? 2015. URL:

http://journals.uoc.edu/index.php/rusc/article/view/v12n1daniel-vazquezgisbert (дата звернення: 29. 04. 2016).

3. Guthrie D. MOOCs are toast or at least should be. 2013 . URL: http://www.forbes.com/sites/dougguthrie/2013/07/ 31/moocs-are-toast-or-should-be/\#462bd90562b2 (дата звернення: 03. 04. 2016).

4. McAuley A. A. et al. The MOOC model for digital practice: Executive Summary. Narrative Introductions. 2010.

5. Sangrá A., González Sanmamed M. \& Anderson T. Metaanalysis of research on MOOC along the period 2013-2014. Educación XXI. 2015. 18 (2). URL: http://revistas.uned.es/ index.php/educacionXX1/article/view/13463 (дата звернення: 03. 04. 2016).

6. Siemens G. What is the theory that underpins our moocs? 2016. URL: http:// goo.gl/nHhCOJ (дата звернення: 24. 04. 2016).

7. Prieto J. L. CVC. Foros. 2007. URL: http://cvc.cervantes.es/ foros/ leer_asunto1.asp? vCodigo=32279 (дата звернення: 30. 04. 2016).

8. Vaszquez-Cano E. \& Meneses E. L. MOOCs and Higher Education: The knowledge expansion. Faculty, 2014. 18 (1). PP. 3-12.

Рецензент: д-р філос. наук, професор Молодиченко В.В.

\section{Information about the authors:}

Dobrovolska SvitlanaRomanivna dobrovolskasr@ukr.net

Lviv National Agrarian University

V. Velykoho St.,1, Dubliany, Zhovkva district, Lviv region, 80381,Ukraine

OpyrMariana Bohdanivna maryanap@ukr.net Lviv National Agrarian University V. Velykoho St.,1, Dubliany, Zhovkva district, Lviv region, 80381, Ukraine

\section{Список використаних джерел}

1. Craik F. I. M., Lockhart R. S. Models of Memory. Introducing Psychological Research. Palgrave, London, 1996.

2. Daniel J., Cano E. V. and Gisbert M. The future of MOOCs: Adaptive learning or business model? 2015. URL:

http://journals.uoc.edu/index.php/rusc/article/view/v12n1daniel-vazquezgisbert (дата звернення: 29. 04. 2016).

3. Guthrie D. MOOCs are toast or at least should be. 2013. URL: http://www.forbes.com/sites/dougguthrie/2013/07/ 31/moocs-are-toast-or-should-be/\#462bd90562b2 (дата звернення: 03. 04. 2016).

4. McAuley A. A. et al. The MOOC model for digital practice: Executive Summary. Narrative Introductions. 2010.

5. Sangrá A., González Sanmamed M. \& Anderson T. Metaanalysis of research on MOOC along the period 2013-2014. Educación XXI. 2015. 18 (2). URL: http://revistas.uned.es/ index.php/educacionXX1/article/view/13463 (дата звернення: 03. 04. 2016).

6. Siemens G. What is the theory that underpins our moocs? 2016. URL: http:// goo.gl/nHhCOJ (дата звернення: 24. 04. 2016).

7. Prieto J. L. CVC. Foros. 2007. URL: http://cvc.cervantes.es/ foros/ leer_asunto1.asp? vCodigo=32279 (дата звернення: 30. 04. 2016).

8. Vaszquez-Cano E. \& Meneses E. L. MOOCs and Higher Education: The knowledge expansion. Faculty, 2014. 18 (1). PP. 3-12. Добровольська Світлана Романівна dobrovolskasr@ukr.net Львівський національний аграрний університет вул. В. Великого, 1, м. Дубляни, Жовківський район, Львівська обл., 80381, Україна

Опир Маріанна Богданівна maryanap@ukr.net Львівський національний аграрний університет вул. В. Великого, 1, м. Дубляни, Жовківський район, Львівська обл., 80381, Україна 
MyronenkoNatalia Vasylivna nataly15999@i.ua

Lviv National Agrarian University

V. Velykoho St.,1, Dubliany, Zhovkva district, Lviv region, 80381, Ukraine

Panchyshyn Svitlana Bohdanivna chorna80@i.ua

Lviv National Agrarian University V. Velykoho St.,1, Dubliany, Zhovkva district, Lviv region, 80381, Ukraine

doi: $10.33842 / 22195203 / 2019 / 23 / 29 / 35$

Received at the editorial office 06. 10. 2019. Accepted for publishing 30. 10. 2019.
Мироненко Наталія Василівна nataly15999@i.ua

Львівський національний аграрний університет

вул. В. Великого, 1, м. Дубляни,

Жовківський район, Львівська обл., 80381, Україна

Панчишин Світлана Богданівна chorna80@i.ua

Львівський національний аграрний університет вул. В. Великого, 1, м. Дубляни,

Жовківський район, Львівська обл., 80381, Україна

doi: $10.33842 / 22195203 / 2019 / 23 / 29 / 35$

Матеріал надійшов до редакиії 06. 10. 2019 p. Прийнято до друку 30. 10. 2019 p. 